\title{
USING HIGH-STAKES STANDARDIZED EXAMINATIONS FOR ESL STUDENTS: CHALLENGES > AND IMPLICATIONS
}

\author{
Sepideh Masoodi \\ University of Calgary, Canada
}

\begin{abstract}
While Alberta is serving a considerable number of English as a Second Language (ESL) ${ }^{1}$ students, these students have been documented to be academically underrepresented compared to their native speaking peers. Within the framework of language policy and planning, this study examines the interplay between the macro and micro levels of the education system in relation to ESL students' educational outcomes. Through a one-year ethnographic study, theperceptions and practices of ESLstudents and their educators in a public school in Alberta were explored. The study explores the implications of using high-stakes standardized examinations as a key indicator of students' outcomes in Alberta.

The study suggests that the provincial achievement tests are not the most appropriate assessment tools to be used for ESL students due to the linguistic and cultural components of the tests. Moreover, these tests continue to impose undesirable changes in school programming and classroom instruction as long as they are dominantly applied in the education system to determine the students' outcomes and evaluate the performance of their schools. There is a need for alternative evaluation measures that could accommodate all students with different linguistic and cultural backgrounds.
\end{abstract}

Keywords: Examinations, students

\section{Introduction}

Canada is a leader in accommodating newcomers from diverse cultural, linguistic, social and economic backgrounds. According to the Census 2006, 20 percent of Canadians counted themselves as Allophones; people who speak a language other than English or French as their first language (Statistics Canada, 2007). An implication of this influx of immigrants is that ESL students comprise an integral part of Canadian school communities. In Alberta, the number of ESL students was estimated to be 37,300 students in 2006 ( $\mathrm{CBE}^{2}$, 2006a; Howard Research and Management 
Consulting Inc., 2006) and Calgary was reported to be the fourth largest city in Canada in terms of the number of immigrants and refugees it received (CBE, 2006a). It was estimated that 58 percent of the new ESL students in Alberta resided in Calgary (Howard Research and Management Consulting Inc., 2006). The population of ESL students in Calgary was estimated at 25,000 students in 2011, whichrepresented 25 percent of the Calgary Board of Education's population (CBE, 2011). The percentage remained unchanged in 2013 (CBE, 2013a).

Learning experiences are different for ESL students compared to students whose native language is English. Their experiences are complicated by many factors, some of which can be considered advantageous, while others may create unique challenges (Alberta Education, 2007). In Alberta, extra help is offered to ESL students who are identified through a coding system. ESL support is provided to enable them to speak the English language fluently, further their education and make a productive contribution to the societies of both Alberta and Canada (Alberta Education, 2013a).The CBE states that the goal of ESL programming is to assist ESL students to reach success in regular academic programs of study (CBE, 2013b).

Within the framework of Language Policy and Planning (LPP), this article looks into the achievement levels of ESL students and the criteria commonly used for assessing their success in the province of Alberta.

\section{Conceptual framework}

The discipline of LPP has evolved over the past 50 years (see Ricento, 2000 for discussion). Nekvapil (2011) referred to language planning as an academic discipline that developed "as a branch of sociolinguistics." Nekvapil elaborated on the historical evolution of language planning and argues that in its earlier form, language planning was described as "decisionmaking" about languages, their implementation and how it could be related to "social planning." The later critical turn in language planning tended to shape the discipline differently by bringing concepts such as social inequality, ideology and agency into the picture. This scholar goes on to add that the field developed to include the "macro" and "micro" dimensions of language management as well.

Chua and Baldauf (2011) also argued that language planning needs to include both macro and micro levels. They emphasize that micro level needs, goals, activities and conditions should be taken into consideration for effective language planning at the macro level.

In this article, I conceptualise the macro and micro level interactions in ESL education discourse within the LPP framework. To elaborate on this, I use themetaphor of an onionwhich was introduced by Ricento and 
Hornberger (1996) to refer to the multi-layered nature of LPP and illustrates how the macro level official or non-official policies interact and interplay with the micro level domains including, classroom level interpretation and implementation of the policies. This article addresses the gap in language policy research that was pointed out by Ricento (2000) when he argued that LPP is not fully accounting for the interactions between the macro and micro levels. Ricento and Hornberger (1996) emphasize the role of classroom practitioners in the processes that lead to the implementation of language policies. Moreover, they suggest that looking into micro level practices and their interaction with macro level discourses can shed light on the multilayered construct of LPP. This research intends to capture the interaction and interplay between the macro and micro level domains of ESL education, including the evaluation and assessment of ESL students' academic achievements and the notion of success for these students.

\section{Macro level ESL discourse}

While celebrating the richness of the cultural heritage that Canada has embraced, the Canadian government aims to promote social cohesion by encouraging immigrant communities to enhance their level of social, cultural and economic integration, according to the Minister of Canadian Heritage, Status of Women and Official Languages and the Secretary of State (Multiculturalism and Canadian Identity) (Canadian Heritage, 2008). The essentialness of such integration was reiterated by the Minister of Citizenship, Immigration and Multiculturalism in a message where he referred to pluralism as "a pillar of Canadian society" (CIC $\left.{ }^{3}, 2011\right)$. Proficiency in one of Canada's official languages is one of the fundamental assets that new settlers should have in order to overcome the barriers that may exist on their way to integration. The Minister of Citizenship, Immigration and Multiculturalism referred to linguistic competence as "a pathway to socio economic integration" at the Eleventh National Metropolis Conference in Alberta (CIC, 2009a). In another of his speeches (CIC, 2009b), he emphasized that "language ability" is the "ultimate tool for" social, cultural and economic integration. While these speeches seem to primarily target adult settlers, the meaningful integration of younger generationsof immigrants also depends on their mastering Canada's official languages. Having recognized the importance of language learning for young immigrants, the Government of Canada has provided supportive programs to help these students in school. A maximum of seven years of ESL instruction is provided for eligible ESL students in Albertato help them achieve grade level expectations in regular subject areas (Alberta Education, 2007).

However, when it comes to ESL students' academic accomplishments, a shortage of studies on ESL students' educational 
achievements has been noted. When it is available, research indicates that ESL students' academic outcomes are unsatisfactory (e.g., Ashworth, 1992; Duffy, 2005; Early, 1992). Derwing, DeCorby, Ichikawa and Jamieson (1999), Roessingh (2004) andWatt and Roessingh (2001) highlighted the higher dropout rate of ESL students and their lower performance on Provincial Achievement Tests (PATs) and Diploma Examinations (DEs) when compared to their Native English Speaker (NS) peers. On the provincial level, Howard Research and Management Consulting Inc. (2006) reported that NS students' achievement outcomes are generally higher than ESL students' academic results. This study found, for example, that “...NS students tend to maintain enrolment in the Alberta Education system, are more likely to be moved forward with their age peers, are more likely to complete PATs/DEs, and achieve at higher levels than ESL students at most grade levels" (Howard Research and Management Consulting Inc., 2006, p. 5).Another example is the Education Annual Report 2008-2009 in which the Deputy Minister (Alberta Education, 2009, p. 20) declared that the achievement results for ESL students were "below the results for the overall student population on a number of key indicators."

As it can be noted in the above examples, standardized tests have often been used to determine the educational outcomes of Alberta students. This article focuses on PATs which are administered at grades 3, 6 and 9. It is important to look into the role that PATs play in the educational system since they are frequently used as a key indicator of both NS and ESL students' achievement results at provincial and municipal levels (see CBE reports, 2005, 2006b, 2007, 2008 and 2009; Moffett and Wagner, 1992). Alberta Education (2012a) defines PATs as a tool for monitoring and evaluating province-wide standards of students' achievements. PATs are administered to help schools and parents be informed of the students' progress and evaluatethe instructional outcomes of the programs offered by the schools (Alberta Education, 2013b). In other words, PATs are used as a "system-wide check" of students' achievementscompared to provincial standards (Alberta Education, 2013c).

When it comes to ESL education, Alberta Education (2007) referred to PATs as both a placement and programming tool since these tests can provide detailed information about the students' English language proficiency.PATs results have also been used to evaluate the success rate of educational programs and systems. For example, while reporting higher PATs results for CBE ESL studentsrelative to ESL students' provincial results, the Calgary Board of Education (2009, p. 5) quoted Assistant Deputy Minister, Dr. Jim Dueck who stated "these results demonstrate the CBE's success to the highest degree yet recorded. I believe the CBE has cause to celebrate." 
Probing into the macro level discourse of Alberta Education, standardized tests function as one of the main tools used in Alberta to evaluate students' achievement results; a tool that documents the underachievement of ESL students at the municipal and provincial levels.

\section{Micro level ESL discourse}

To examine the micro level discourse of ESL education, this article looks into the means of evaluating ESL students' achievement results by focusing on the role of the high-stakes standardized tests in the local level context. This article includes part of the data collected through a one-year (2010-2011) ethnographic research study conducted in a public school in Alberta. This school was selected as the study site mainly because it was mandated to exclusively serve the needs of ESL students.

The objective of conducting this study was to investigate the perceptions and daily experiences of ESL students and their educators at the local level of the school and to consider the ways in which the macro level discourse and the policies regulated at the macro level may influence the micro level practices. There was an interest in understanding how the macro level regulations are interpreted and implemented at the school level.

The participants in this study were comprised of 248 ESL designated students, 23 school educators, 27 parents and 14 people in other positions in the school; a total of 312 participants.The results of the study are interpreted from the data that was collected through field observation, interviews with the participants and analysis of the documents available on ESL education. Out of 248 student participants, 73 participated in individual and focus group interviews and others were involved in classroom observations and informal conversations.

Data analysis was conducted through typology and by producing taxonomies. The data collected through field observation and informal conversations with the study participants was used to form the guiding questions for interviews. The data obtained from the interviews was coded to produce patterns. Themes and categories emerged through saturation.

\section{The participants' perception of PATs}

As mentioned earlier, PATs have a dominant role in the macro level discourse of education in Alberta and play a principal role in determining students' outcomes. Similarly, the significant role that PATs play in the educational system could be inferred from the interviews with the school's educators. They stated that PATs were used to demonstrate individual students' learning as well as the school's programming outcomes. Therefore, there was a clear need to prepare the students for the tests. 
However, preparation for the PATs seemed to be a challenging task in the context of the school where the population was exclusively comprised of ESL designated students. All the interviewed educators and parents stated that ESL students needed additional support in their studies to be able to meet the requirements of the programs of studies. The majority of the interviewed students maintained that the one-on-one instruction provided in the school and the ESL strategies applied by the instructors played a significant role in their learning.

\section{Impact of PATs on classroom instruction}

The interviews with the educators and the classroom observations indicated that classroom instruction for ESL students included content delivery of the subject area,as well asinstruction of the language that carried the content. Therefore, preparing ESL students for PATs seemed to impose an additional challenge to the instructor. A grade 3 teacher explained, "English across the curriculum is integrating the language in all subjects as much as possible" thus raising concerns about not fully covering the curriculum in order to enhance the language surrounding it. He added that PATs preparation could put another constraint on the in-depth teaching of the curriculum. However, he explained:

Unofficially, myself and a couple of other grade three teachers... we have agreed that we don't want to take away parts of the curriculum; we want to teach it as well done as possible, and the numbers that the school has posted in terms of the acceptable marks [... show] the fantastic progress that the kids have had, so ... In my idea, if you have a language focus, you can't spend so much time exclusively to choose test teaching... In a way, it is good because there is vocabulary and expressions that go with the test teaching but... but the more things you have to draw and teach, the more opportunities you have to integrate reading and writing and oral language as well.

He added that it was important to prepare the students for PATs "by having them understand the instructions and being able to do some logical linking to figure out what wasexactly being asked." He explained the difficulties that the students might face while answering the test items:

I have a higher group; so, their understanding of the concept is strong, but on the test when we are not monitoring their answers, they often get things wrong because they simply don't get the question. They need some help to reword the instructions for them or just tell them what to do. So, they are good readers. Most of their reading comprehension is quite high, but they are struggling and have trouble with instructions. 
He emphasized the role that vocabulary repertoire can play in an ESL student'sperformance. He suggested that vocabulary instructions should be "much more explicit and much more in depth" for ESL students.

The concern about English vocabulary was raised by the students as well. The majority of the students indicated that a lack of adequate knowledge ofEnglish vocabulary was a major area challenging them while learning the contents of a subject. Here are some quotes from the students explaining the difficulties that theyfaced due to their level of English vocabulary:

A student in Grade 5 explained:

Sometimes my mom says me a word and I don't understand them.

I usually know more words in Arabic and she tells me in Arabic and if I don't know she describes and defines those words.

Several students in grade 1 mentioned that they might not understand all the wordsif the teacher talked fast. One of them said:

You are not smart in words; you cannot figure out the problem. Another student added:

If a teacher says something that you don't understand a big word, and she explains that, and you don't know what she's talking about; what could you do.

A grade 5 student explained:

Sometimes we don't know the words, then the sentence is confusing.

The challenges that students faced due to the level of their English vocabulary were mentioned by the students at all grades. A grade 9 student noted:“... when it comes to social big words and science big words, I don't understand as much. That's why I have to go and ask teachers and they help me out.”

The conversations with these ESL students and their teachers concur with the results of the studies conducted by Douglas (2010) and Roessingh (2010). Their research indicates a correlation between vocabulary repertoire and ESL students' academic success.

\section{ESL students' preparation for PATs}

While the school educators raised concerns about the preparation for PATs resulting in an extra challenge on ESL education, they all stated that it was necessary to prepare the students for the tests. One of the grade 3 teachers referred to the outstanding results that the school had achieved that year in the grade 3 PATs. She emphasized that to achieve satisfactory results, it was essential to prepare the students for the tests by familiarizing them with the writing format of the tests and the grammatical structures that might appear on them. She added that the reading portion of the tests could create 
more challenges than the writing part as the students might not have "enough language" to thoroughly comprehend the reading part. She explained that ESL students would often require a higher level of preparedness for the tests compared to their NS peers. She suggests that "intentional language teaching" and "repeated exposure" in terms of reading was necessary to familiarize these students with the vocabulary and the types of questions that might appear on the tests.

However, she stated that, despite such preparation, the results of the tests might vary, depending partly on the difficulty level of the tests each year. She added that it was important to assist the students in obtaining acceptable results since the parents regarded these tests as one of the main indicators of the students' academic performance and improvement.

She restated that it would be possible for ESL students to perform well on PATs provided that both the teacher and the students make "extra effort." However, in her final words, she added that PATs should be viewed as only one of the indicators of students' achievements and that more attention needed to be paid to the emotional and personal factors influencing the students' learning, such as motivation.

The extra pressure that PATs could put on ESL instruction was noted by the teachers of grades 6 and 9 as well. Moreover, they raised concerns in terms of the appropriateness of the standardized tests for ESL students. One of the middle school teachers suggested that PATs might create more challenges for ESL students relative to mainstream students as ESL studentsmight not be able to relate to some of the themes or vocabulary appearing on the tests. These difficulties could result from the differences in the life experiences of these students and their degree of familiarity with Canadian culture and lifestyle. However, he stated that the students could be prepared for the PATs byusing ESL/ELL strategies and differentiated instruction. He emphasized that ESL students should be taught tomaster the skills that are required for writing standardized tests beginning in kindergarten and continuing through post-secondary education.

One theme that emerged from the conversations with the educators was that the cultural content of the standardized tests might not be suitable for ESL students coming from diverse cultural backgrounds. A grade 9 teacher who could personally relate to the experiences of ESL students stated that PATs were not the most culturally appropriate tests for these students. However, he commented that the students had the potential to be wellprepared for the tests. He added that these tests could function as integration tools and ESL students had to be assessed based on the comprehensive system that was used "on the board" in the province. Moreover, he pointed out that developing alternative or supplementary assessment tools toevaluate ESL students' achievement results might be another option to consider;but 
standardizing alternative tests to assess both the mainstream and ESL students in a similar way might not be feasible. Therefore, he concluded that the main concern should probably be "whether PAT is the right path for everybody in the province."

Another middle school instructorpointed out the same issue. She said that the tests' incompatibility with ESL students' cultural backgrounds stemmed from the fact that the tests were designed to target mainstream education students and that "the cultural piece [was] missing for these kids because some of them [didn't] even engage in Canadian culture the way that mainstream students [did]." She added: "They are designed for just one group of the population; it is not representative of the whole population."

She also pointed out another difficulty that ESL students might face when writing PATs. She said that these students often needed additional time for the reading comprehension part of the tests. She continued that it might take longer for ESL students to read, process and internalize the substance of the test items since these studentsmight be "very literal," and would often face difficulties in "comprehending the abstract contents of the tests." She explained that "figurative language," "sayings," "proverbs" and "analogies" were the troublesome areas for these students, especially since these linguistic elements would often carry cultural themes as well. She noted that sometimes the amount of reading could be extensive for ESL students and they might not be able to finish the test, even if they were given extra time, which could be frustrating and discouraging for them. She hoped that the tests would be modified to address the needs of ESL students.

Another school educator who taught grades 6 and 8 science, commented that PATs are challenging for ESL students because theyoften know the concepts asked by the questions and their solutions, but it is the linguistic level of the test items that could prevent the students from performing well on the tests. However, she continued that, since the student population in the school was exclusively comprised of ESL learners, school programming was specifically geared towards teaching the language alongside the content. This programming has resulted in improvement in their ESL students' performance on PATs.

Another teacher commented:“That's a pressure ... And unfortunately when it comes to that provincials, it is not about 'are we getting the kids ahead to learn'... It's based on one test."

Based on the educators' comments, it appears that, while PATs are provincially accredited and applied, ESL students seem to be at a disadvantage compared to their NS peers when it comes to the cultural and linguistic components of the tests. Alberta Education (2007, p. 29) acknowledged this matter by stating, "Standardized tests for English speaking students are based on linguistic and cultural norms that are not 
appropriate for ESL students.” Large-scale standardized tests have been questioned for their validity for ESL students as their content and types, as well as their contextual and cultural aspects, are designed and constructed for NS (Cheng, Klinger and Zheng, 2007, Kobayashi, 2002, Lee, 2002), PATs are no exception.

\section{ESL education and application of PATs}

The school educators were questioned about positioning ESL students in relation to the tests and whether they would deem the tests necessary for these students. The interviewed teachers for grades 3, 6 and 9 stated that, as long as standardized tests were used as a key indicator of performance, ESL students should be given access to them like any other student. The school administrators expressed similar opinions.

One of the school administratorsstated that PATs should be available to both mainstream and ESL students because he believed that"ELL students can do as well on the provincial achievement tests as any other child.” He continued that the school had proven ESL students'potential to achieve outstanding results on PATs.He noted that preparing these learners for the tests and eventually for their successful integration into the mainstream education system was their role in the education system. He stated: "We need to support them so that they do well and I believe that we are seeing that type of success."

Another school administratoralso acknowledged the advantages of applying the standardized assessment tools, especially for the purpose of ascertaining that "teaching [was] happening at the standardized level" and that the curriculum guidelines were observed across the province. She believed that PATs should be available to ESL students to give them the opportunity to overcome that challenge. However, she pointed out that the tests might not be a fair assessment for students with low English proficiency levels. She added that the tests were not "the best assessment tools" and could be regarded as only "a part of the [student] portfolio;" one of the multiple indicators of students' performance.

Looking into the education system at the school level, it can be inferred that standardized tests are regarded as one of the major factors in determining both the students' outcomes and the school programming. ESL students require a greater understanding of the test requirements and should be prepared for the PATs through intentional instruction and specific supportive programming. Employing alternative and supplementary assessment tools, as well as multiple evaluation techniques for the evaluation of ESL students' academic performance, were strongly recommended by the school's educators. 


\section{Discussion}

Improving the students' achievement results and assisting them in reaching success have been the ultimate goals of Alberta's education system (Alberta Education, 2012b).In this province, the success rate in the students' achievement outcomes is often measured through standardized tests, includingPATs. This article argues that the significant role that these tests play in determining the outcomes of educational programs and the students' learningresultscanhave a major impact on planning and implementingschool programming and classroom instruction. In other words, the policies and guidelines regulated at the macro level of the education systemcan influence and shape the daily practices of the educators at the local level of the schools, the educational experiences of the students and their parents' involvement and expectations. This concurs with Jardine (2005), whose research discussed how educators and students are affected by the constraintsset by educational regulations. Jardine stated: "We often find ourselves put in the position of being subjected to school and state/provincial-level expectations which often do to us what we, in turn, are influenced to do to children" (p. 3).This study shows the influentialrole that PATs play at the macro level of educational discourse and, consequently, on the local level practices of school instructors.

Application of PATs as principal indicators of students' academic performance can lead to undesirable outcomes in the effectiveness of program delivery. Jardine (2000) quoted from teachers who expressed that they are in "constant tension" since they believe in "the effects that [their] decision has on [their] students each time [they] must choose to skim over helping [their] students learn in meaningful ways in order to teach so that [their] students will be well prepared and able to achieve high scores on their standardized provincial achievement tests" (p. 5).Jardine (2005) further relied on "Foucault's historical and philosophical analyses" and elaborated on the "conscious and unconscious" reactions that educators may show to "standardized curricula and standardized testing" and the "actual [negative] effects" of the tests on the education system.

While using high-stakes standardized tests are an increasingly common practice in many parts of North America, the validity issues of the tests have been questioned when they are used to evaluate the achievement results of students with special needs, including ESL learners. For example, application of standardized tests in the United states (Solórzano, 2008), Ontario (Cheng, et al., 2007) and British Colombia(Gunderson, 2007) have been identified as a factor creating extra challenges to ESL students' academic success, the performance of their instructors and the school programming. Standardised tests mandated by some provinces negatively impact second language acquisition in schools since teachers tend to deliver 
the programs towards the needs of the tests, which may not correspond to the students' diverse needs (Jia, Eslami and Burlbaw, 2006; Meyers, 2006). This study confirms thatthe urge to accommodate the requirements of the tests may influence school programming. For example, classroom instruction may be geared towards test preparation at the expense of thorough curriculum delivery.

The appropriateness of the tests is also questioned by ESL educators in relation to the cultural and linguistic components of the tests. The study suggests that the life experiences of ESL students might be different from their NS peers since they may not have the same exposure to the mainstream linguistic and cultural norms. ESL populations can be at a disadvantage when it comes to writing standardized tests that are developed based on these norms.

While standardized tests have been questioned for their usefulness and fairness in evaluating ESL students' academic outcomes (Jia, Eslami and Burlbaw, 2006; Huang, 2008; Mahon, 2006), the participants in this study call for an alternative and more appropriate evaluation system for ESL students. However, assessment and evaluation of students with special needs, including ESL students, is a challenge for the education system as those populations are often not assessed appropriately and according to their specific needs (Wormeli, 2006). Eliciting the points of view of the stakeholders and experts in ESL education in Alberta, Howard Research and Management Consulting Inc.(2006) reported a lack of proper assessment tools which specifically address ESL students' needs.

In a study conducted in Alberta, Webber, Aitken, Lupart and Scott (2009) questioned the appropriateness of standardized tests when used as "league tables" for comparison purposes in the education system. While they referred to the vast range of available assessment practices applied in the province (see Webber et al., 2009), they emphasized the critical role that classroom teachers play in students' assessment and evaluation. They commented, "Most decision making about students' educational programming is premised upon the information generated by classroom teachers” (p. 1). The significant role that classroom educators can play in students' assessments was also stated by Jardine (2005). She stressed the importance that should be given to "the localized particular knowledge" of educators and the "differentiated knowledge" gained through teachers' dayto-day practices. Similarly, when it comes to ESL education, the teacher's assessment is one of the frequently suggested approaches for the evaluation of these students. Long-term, ongoing monitoring of ESL students' progress and their programming has been referred to as an alternative assessment (Jia, Eslami and Burlbaw, 2006; Lee, 2007; Ragan andLesaux, 2006). 
However, in their study, Webber et al. (2009) argued that "teachers in general are not proficient in student assessment practices in Alberta ...”(p. 6.) Moreover, Jia, Eslami and Burlbaw (2006) maintained that internal and externalfactors, such as state-wide standardized tests, parental expectations, number of students and materials, can influence teachers' assessments of ESL students. The current study concurs that various factors, including parental expectations, policy requirements regarding PATs and time can have a significant impact on the teachers' instructional practices.

There is evidently a need to develop alternative or supplementary assessment tools in the province. In this regard, Webber et al. (2009) suggested developing "a holistic framework for classroom assessment" in Alberta and recommended the use of differentiated assessment that could "accommodate the ability, social, cultural, and linguistic needs of every student” (p. 146).However, the callto develop evaluation measures which could be appropriately used in both the mainstream and special education continues.

\section{Conclusion}

By looking at macro and micro levels of the education system, this study suggests that the policies and regulations set at the provincial or municipal levels are reflected in the daily practices of the students and their educators. By focusing on the role of standardized tests in the education system, this study shows that, as long as the macro level discourse acknowledges standardized tests as the prominent tool for evaluating educational outcomes, the educational practices at the locallevel of the schools should be adjusted to accommodate the preparation for the tests.

After carefully considering the role of standardized tests in the education of ESL students in Alberta, this study suggests that, while standardized tests could have potential benefits for the education system as defined by the objectives set for their application, they could lead to controversy when used to evaluate ESL students' outcomes. The demands of the tests may impose undesirable changes in school and classroom programming which can affect the effectiveness of the instruction and the students' learning. The tests are also questioned for their fairness in terms of their linguistic and cultural demands. Therefore, the application of these tests may lead to disproportionate representation of ESL students' outcomes compared to their NS peers. This study suggests that it is necessary to create targeted support for these students in order to minimize the consequences of the irrelevant factors inherent in the tests.

ESL students are documented as one of the disadvantaged groups in the education system,especially when their academic achievements are compared to NS students. The under-representation of ESL students can be a 
challenge for the ESL population, their parents, their school educators and the education system.To preserve ESL students' rights in having equal opportunities to education and improving the educational programs offered to them, more attention should be given to the local experiences of the students and their educators. The local requirements of these students need to be understood and met to facilitate their integration into Canadian society. This will guide the education system in reaching its ultimate goal, which is success for all students.

\section{Notes}

${ }^{1}$ Discussions on English language education have often highlighted the complexities inherent in dichotic categorizations such as "ESL" versus "NS" (e.g. Davis, 2013; Phillipson, 2000; Ricento, 2005). In this article, the terms "ESL" and "NS" have been used with reference to Alberta Education and Calgary Board of Education's publicly available documents and the studies mentioned in the article. However, the author recognizes the highly heterogeneous characteristics of the student population.

The terms, ESL and ELL,have often been used interchangeably in the discourse of English language education (e.g. Batt, 2008; Ortmeiere-Hooper, 2008; Sandefur, Watson and Johnston, 2007). Since these two terms are often used synonymously in most documents published by Alberta Education and the Calgary Board of Education to refer to the same population and their education in Alberta (e.g. CBE, 2013a;LearnAlberta, n.d.), ESL is used as the umbrella term in this study torepresent the ESL/ELL population.

${ }^{2}$ Calgary Board of Education (CBE)

${ }^{3}$ Citizenship and Immigration Canada (CIC)

\section{References:}

Alberta Education (2007).English as a Second Language K-9 Guide to Implementation. Edmonton, AB: Alberta Education. Retrieved June 2013, from http://education.alberta.ca/media/507659/eslkto9gi.pdf

Alberta Education (2009).Education Annual Report 2008-2009. Edmonton, AB: Alberta Education. Retrieved June 2013, from http://education. alberta.ca/media/1117318/overview2008-09.pdf

Alberta Education (2012a).Provincial Achievement Tests,General Information Bulletin.2012-2013 School Year. Edmonton, AB: Alberta Education. Retrieved June 2013, from http://education.alberta.ca/ media/6419101/01-ach-gib-2012-13_toc_2012-11-28.pdf

Alberta Education (2012b).Your Voice Matters [Parents' Survey]. Edmonton, AB: Alberta Education. 
Alberta Education (2013a). English as a Second Language. Edmonton, AB: Alberta Education. Retrieved June 2013, from http://education.alberta. ca/teachers/program/esl.aspx

Alberta Education (2013b). Achievement Tests and Diploma Exams: PowerPoint Presentation. Edmonton, AB: Alberta Education. Retrieved June 2013, from http://education.alberta.ca/parents/resources/exams.aspx

Alberta Education (2013c). Alberta's Commission on Learning, Making the Grade.Edmonton, AB: Alberta Education. Retrieved June 2013, from http://education.alberta.ca/department/ipr/archive/commission/report/highlig hts/keydir/grade.aspx

Ashworth, M. (1992).Views and visions.In B. Burnaby \& A. Cumming (Eds.).Socio-political Aspects of ESL (35-50). Toronto: The Ontario Institute for Studies in Education

Batt, E. G. (2008). Teachers' perceptions of ELL education: Potential solutions to overcome the greatest challenges. Multicultural Education, 15 (3), 39-43

Calgary Board of Education (2005, May).School Newsletter Inserts. Calgary, AB: Calgary Board of Education. Retrieved September 2009, from http://www.cbe.ab.ca/AboutUs/schoolinsert/fromMay05.pdf

Calgary Board of Education. (2006a). Building a Strong Community. Calgary, AB: Calgary Board of Education. Retrieved April 2013, from http://www.cbe.ab.ca/new/esl/100esl[1].ppt

Calgary Board of Education (2006b, Aug.-Sep.).School Newsletter Inserts. Calgary, AB: Calgary Board of Education. Retrieved September 2009, from http://www.cbe.ab.ca/AboutUs/schoolinsert/fromAug-Sep06.pdf

Calgary Board of Education (2007, Nov.).School Newsletter Inserts. Calgary, AB: Calgary Board of Education. Retrieved September 2009, from http://www.cbe.ab.ca/aboutus/schoolinsert/Nov_2007.pdf

Calgary Board of Education (2008, Nov.).School Newsletter Inserts. Calgary, AB: Calgary Board of Education. Retrieved September 2009, from http://www.cbe.ab.ca/aboutus/schoolinsert/Nov_2008.pdf

Calgary Board of Education. (2009). Report to the Community. Calgary, AB: Calgary Board of Education. Retrieved June 2013, from http://www.cbe. ab.ca/aboutus/documents/ReportToCommunity2009/index.html

Calgary Board of Education. (2011). Programming for English Language Learners. Calgary, Alberta: Calgary Board of Education. Retrieved February 2012, from http://www.cbe.ab.ca/programs/prog-esl.asp

Calgary Board of Education (2013a).Programming for English Language Learners.Calgary, Alberta: Calgary Board of Education. Retrieved June 2013, from http://www.cbe.ab.ca/programs/prog-esl.asp 
Calgary Board of Education (2013b).ESL Coding.Calgary, Alberta: Calgary Board of Education. Retrieved June 2013, from http://www.cbe.ab.ca/ programs/prog-pdf/Bucket_ESL_coding.pdf

Canadian Heritage (2008).Promoting Integration: Annual Report on the Operation of Canadian Multiculturalism Act 2006-2007. Gatineau, Quebec: Canadian Heritage. Retrieved June 2013, from http://www.cic.gc.ca/ English/pdf/pub/multi-report2007.pdf

Cheng, L., Klinger, D. \&Zheng, Y. (2007). The challenges of the Ontario Secondary School Literacy Test for second language students. Language Testing, 24 (2), 185-208.

Chua, S. K. C. \&Baldauf, R. B., Jr (2011).Micro language planning.In E. Hinkel. (Ed.). Handbook of Research in Second Language Teaching and Learning, Volume II. (936-952). New York: Routledge Taylor and Francis Group

Citizenship and Immigration Canada (2009a).Speaking Notes for the Honourable Jason Kenney, P.C., M. P. Minister of Citizenship, Immigration and Multiculturalism at the Eleventh National Metropolis Conference, Calgary, Alberta, March 20, 2009. Retrieved June 2013,from http://www.cic.gc.ca/English/department/media/speeches/2009/2009-0320.asp\#cont\%20idcont

Citizenship and Immigration Canada (2009b).Remarks by the Honourable Jason Kenney, P.C., M.P. Minister of Citizenship, Immigration and Multiculturalism at the Immigrant Language and Vocational Assessment Referral Center to Announce a Pilot Program for Language Training Vouchers, Calgary, Alberta, October 16, 2009. Retrieved June 2013, from http://www.cic.gc.ca/English/department/media/speeches/2009/2009-1016.asp

Citizenship and Immigration Canada (2011).Promoting Integration: Annual Report on the Operation of Canadian Multiculturalism Act 2009-2010. Ottawa, ON: CIC. Retrieved June 2013, from http://www.cic.gc.ca/ English/pdf/pub/multi-report2010.pdf

Davies, A. (2013). Native Speakers and Native Users: Loss and Gain. Cambridge, UK: Cambridge University Press.

Derwing, T. M., DeCorby, E., Ichikawa, J. \& Jamieson, K. (1999).Some factors that affect the success of ESL high school students.Canadian Modern Language Review. 55(4), 532-47

Douglas, S. R. (2010). Non-Native English Speaking Student at University: Lexical Richness and Academic Success. PhD dissertation, Calgary, University of Calgary.

Duffy A. (2005). ESL: A call for research. Education Canada, 45(3), 56 
Early, M. (1992).Aspects of becoming an academically successful ESL student. In B. Burnaby \& A. Cumming (Eds.). Socio-political Aspects of ESL (265-276). Toronto: The Ontario Institute for Studies in Education Gunderson, L. (2007). English-only instruction and immigrant students in secondary schools: A critical examination. Mahwah, NJ: Lawrence Erlbaum Howard Research \& Management Consulting Inc. (2006). Review of ESL K12 Program Implementation in Alberta: Final Report. Edmonton, AB: Alberta Education. Retrieved June 2013, from http://education. alberta.ca/media/353509/review_of_esl_full_report.pdf

Huang, J. (2008). How accurate are ESL students' holistic writing scores on large-scale assessments? - A generalizability theory approach. Assessing Writing, 13, 201-218

Jardine, G. M. (2005). Foucault and Education. New York: Peter Lang Jardine, P. G. (2000). Understanding generative curriculum: a hermeneutic and ecological exploration. Unpublished dissertation, Alberta, University of Calgary.In Jardine, G. M. (2005).Foucault and Education. New York: Peter Lang

Jia, Y., Eslami, Z. R. \&Burlbaw, L. M. (2006).ESL teachers’ perceptions and factors influencing their use of classroom-based reading assessment. Bilingual Research Journal, 30(2), 407-430

Kobayashi, M. (2002). Method effects on reading comprehension test performance: Text organization and response format. Language Testing, 19, 193-220

LearnAlberta (n.d).Supporting English Language Learners. Alberta: Government of Alberta. Retrieved June 2013, from http://www.learnalberta. ca/content/eslapb/search.html

Lee, G. (2002). The influence of several factors on reliability for complex reading comprehension tests. Journal of Educational Measurement, 39. 149164

Lee, I. (2007). Assessment for learning: integrating assessment, teaching, and learning in the ESL/EFL writing classroom. The Canadian Modern Language Review, 64(1). 199-214

Mahon, E. (2006). High-stakes testing and English language learners: questions of validity. Bilingual Research Journal, 30(2), 479-497

Meyers, M. (2006). Myths and delusions: English language instruction in Canadian schools. Education Canada, 46(2), 31-34

Moffett, J., \& Wagner, B. J. (1992).Student-centered Language Arts, K-12 (4th ed.). Portsmouth NH: Boynton/Cook Publishers

Nekvapil, J. (2011). The history and theory of language planning.In E. Hinkel. (Ed.). Handbook of Research in Second Language Teaching and Learning, Volume II. (871-888). New York: Routledge Taylor and Francis Group 
Ortmeier-Hooper, C. (2008). English may be my second language, but I'm not 'ESL'. College Composition and Communication, 59 (3), 389-419 Phillipson, R. (2000). English in the new world order, In T. Ricento (Ed.), Ideology, Politics and Language Policies: Focus on English (87-106). Amsterdam: Benjamins.

Ragan, A. \&Lesaux, N. (2006). Federal, state, and district level English language learners program entry and exit requirements: effects on the education of language minority learners. Education Policy Analysis Archives, 14(20), 1-32

Ricento, T. (2000).Historical and theoretical perspectives in language policy and planning. Journal of Sociolinguistics, 4(2), 196-213

Ricento, T. (2005).Considerations of identity in L2 learning.In E. Hinkel (Ed.).Handbook of Research on Second Language Teaching and Learning (895-911). Mahwah, NJ: Lawrence Erlbaum Associates.

Ricento, T. \&Hornberger, N.H. (1996). Unpeeling the onion: language planning and policy and the ELT professional.TESOL Quarterly, 30(3), 401427

Roessingh, H. (2004). Effective high school ESL programs: a synthesis and meta-analysis. Canadian Modern Language Review, 60 (5), 611-636

Roessingh, H. (2010). How many words do you know: language, learning and literacy for K-12 and beyond.Engaging New Ideas in Lecture Series. Faculty of Education, University of Calgary

Sandefur, S. J., Watson, S. W. \& Johnston, L. B. (2007). Literacy development, science curriculum, and the adolescent English language learner: Modifying instruction for the English-only classroom. Multicultural Education, 14 (3), 41-50

Solórzano, R. W. (2008). High stakes testing: Issues, implications, and remedies for English language learners. Review of Educational Research, 78, (2), 260-329

Statistics Canada (2007).2006 Census: Immigration, Citizenship, Language, Mobility and Migration. Ontario: Statistics Canada. Retrieved June 2013, from http://www.statcan.gc.ca/daily-quotidien/071204/dq071204a-eng.htm Watt, D. \&Roessingh, H. (2001). The dynamics of ESL drop-out: "plus ca change”. Canadian Modern Language Review, 58 (2), 203-22

Webber, C. F., Aitken, N., Lupart, J. \& Scott, S. (2009). The Alberta Student Assessment Study: Final Report. Edmonton, AB: Alberta Education

Wormeli, R. (2006). Fair Isn't Always Equal. Assessing and Grading in the Differentiated Classroom. Portland, ME: Stenhouse 